\title{
NUCLEAR SAFETY OF DISPOSAL FACILITIES FOR RADIOACTIVE WASTE CONTAINING FISSILE NUCLEAR MATERIALS
}

\author{
Vnukov V. S., Ryazanov B. G., Sviridov V. I. \\ Joint Stock Company «State Scientific Centre of the Russian Federation - Institute for Physics \\ and Power Engineering named after A. I. Leypunsky», Obninsk, Russia
}

Article received on June 4, 2019

\begin{abstract}
The article focuses on different approaches aiming to ensure nuclear safety at disposal facilities for radioactive waste containing fissile nuclear materials. The approaches vary depending on the type and design of disposal facilities with due account of their evolution scenarios. The article discusses the methods enabling to identify the amount of fissile radionuclides contained in the radioactive waste subject to disposal.
\end{abstract}

Key words: radioactive waste, nuclear safety, disposal facility for radioactive waste, fissile nuclear materials, long-term nuclear safety, disposal facility evolution scenarios.

Pursuant to Russian legislative provisions, all radioactive waste (RW) shall be disposed of in RW disposal facilities (RWDF) designed to ensure protection of public and the environment from harmful effects of ionizing radiation for the entire period of the potential hazard posed by the waste [1]. The potential hazard period of waste can vary from hundreds to hundreds of thousands of years. For this reason, long-term safety assessments of RWDF should account for the changes in the disposal setting, the properties of structural materials and RW materials. Depending on activity and radiological hazard, six classes of RW can be singled out [2]. Most hazardous waste (RW classes 1, 2 and 5) shall be disposed of in deep disposal facilities (RW DDF and LRW DDF), and the rest - in near-surface disposal facilities (NSDF) [2]. Waste segregation by disposal method is also explained by relevant radiation hazard periods. In case if the content of nuclear hazardous fissile nuclides (NFN) in the disposed waste is low, then the volume of RW in the disposal facility will amount to thousands of cubic meters with NFN mass amounting to tens or even hundreds of kilograms. Thus, the possibility of a self-sustaining fission chain reaction (SCR) cannot be excluded a priori.

Nuclear safety is considered as a most important safety indicator for RWDFs, which primary depends on the amount of nuclear fissile materials contained in the disposed RW.

Nuclear and radiation safety of RWDF shall be ensured for a time period associated with the hazard posed by the waste (from 300 to 1,000 years). NFNs have long half-lives. For example, the half-life of ${ }^{235} \mathrm{U}$ is about 700 million years, ${ }^{239} \mathrm{Pu}$ has a half-life of about 24 thousand years. Therefore, in nuclear hazard assessments, one should consider the longterm processes potentially resulting in formation of an above critical system in the RWDF. These processes may refer to the destruction of matrix materials ensuring waste containment, their compaction, changes in the chemical and mineralogical composition of rocks driven by geological processes occurring in the RW disposal area, RW interaction 
with the host rocks, NFN leakage from containers, NFN release into groundwater and spread in the geological environment, possible NFN concentration due to certain geochemical processes.

Therefore, nuclear safety conditions established based on the review of RWDF design materials with no account of the disposal system's development and evolution scenarios in general, including its design and the natural setting at the site, basically, do not allow to exclude the possibility of SCR even if the requirements on NFN content in the disposed waste are observed. Moreover, they do not allow to identify its parameters, the mechanisms for suppressing possible SCR after the expiration of the forecast period.

Management of RW containing NFNs, certification of packages and batches of waste prior to their hand over for disposal is carried out by operating organizations generating the waste. The operating organizations shall also ensure waste conditioning bringing it in line with waste acceptance criteria set for particular RW disposal facilities.

Requirements on nuclear safety, accounting and control of nuclear materials at nuclear fuel cycle facilities (NFCs) during their handling, including radioactive waste containing NFN, are set forth in federal rules [3-6], standards of the State Atomic Energy Corporation Rosatom [7, 8] and nuclear safety statements. The requirements, criteria and norms, including those addressing accounting and control of nuclear materials, are quite sufficient to ensure nuclear safety during the management of waste and waste packages throughout their temporary storage at relevant facilities and transportation to RWDF.

General safety requirements and RW acceptance criteria for disposal are set forth in the provisions of federal norms and rules [9-12] and can be summarized as follows:

- a passport (certificate) should be filled in for the waste handed over for disposal, containing, in particular, data on its isotopic composition and specific activity. The passport should be filled in by the organization that generated the waste or by the organization responsible for the waste treatment and conditioning;

- when accepting the RW handed over for disposal, the National Operator for RW management is responsible for its control with the attributive features of the transferred packages and waste batches being checked;

- RW packages containing NFN shall comply with nuclear safety requirements set forth by relevant provision of federal norms and rules in the field of atomic energy use;

- RW compliance with waste acceptance criteria for disposal shall be confirmed by experimental (instrumental) and (or) calculation methods, provided that these are based on preliminary direct and (or) indirect measurements of the controlled process parameters;

- characteristics and properties of the radioactive waste sent for disposal shall be identified for the entire volume of the waste and the accuracy of such evaluations shall allow to confirm its compliance with waste acceptance criteria for disposal. Concentration of NFN in LRW being injected into LRW DDF should be limited in order to exclude the possibility of SCR taking into account LRW concentration during its migration in reservoir beds. NFN concentration in LRW should not exceed the limits established for a particular LRW DDF in accordance with nuclear safety requirements specified in relevant federal norms and rules in the field of atomic energy use.

Thus, to demonstrate the long-term nuclear safety in general, the following basic questions should be answered:

- Is there a possibility for NFNs release from RW and their concentration in the rocks, and if so, what is the composition of these rocks and what is the NFN concentration limit for them?

- whether NFN fractionation (leaching, extraction, sorption) is possible (for example, separation of uranium and plutonium) and what will be the maximum concentrations due to external events and evolution?

By answering these questions one can say if a supercritical system can potentially evolve suggesting that NFN concentration/content in the rock will exceed the minimum critical value for the predicted composition. If the answer is yes, then whether the NFN mass exceeds the critical value set for the system with an assumed composition. It should be noted that, basically, the total accumulated NFN mass in RW DDF is much higher than the minimum critical value.

Even for ${ }^{235} \mathrm{U}$ mixtures with effective moderators without any thermal neutron absorbers (for example, iron, aluminum, nickel), relevant safe critical contents are much higher than the process values (less than $10 \mathrm{mg} / \mathrm{kg}$ ). For example, relevant values for ${ }^{235} \mathrm{U}$ mixtures with simple substances are assumed to be as follows:

$$
\begin{aligned}
& \left(\mathrm{MgF}_{2}+{ }^{235} \mathrm{U}\right)-0.25 \mathrm{~g}{ }^{235} \mathrm{U} / \mathrm{kg} \\
& \left(\mathrm{CaF}_{2}+{ }^{235} \mathrm{U}\right)-0.425 \mathrm{~g}{ }^{235} \mathrm{U} / \mathrm{kg} ; \\
& \left(\mathrm{H}_{2} \mathrm{O} / \mathrm{CH}_{2}+{ }^{235} \mathrm{U}\right)-9 \mathrm{~g}^{235} \mathrm{U} / \mathrm{kg} \\
& \left(\mathrm{C}+{ }^{235} \mathrm{U}\right)-0.08 \mathrm{~g}^{235} \mathrm{U} / \mathrm{kg} \\
& \left(\mathrm{SiO}_{2}+{ }^{235} \mathrm{U}\right)-0.8 \mathrm{~g} \mathrm{~g}^{235} \mathrm{U} / \mathrm{kg}
\end{aligned}
$$

Safe critical concentrations for ${ }^{239} \mathrm{Pu}$ mixtures with these substances are close to the abovementioned ones and vary from 0.05 to $7 \mathrm{~g}$ of ${ }^{239} \mathrm{Pu} / \mathrm{kg}$.

Thus, SCR in a RWDF can be ruled out if, as a result of external events and disposal system evolution, 
the possibility of NFN concentration ${ }^{235} \mathrm{U},{ }^{239} \mathrm{Pu}$, ${ }^{241} \mathrm{Pu}$ ) in the radioactive waste to more than $0.05 \mathrm{~g}$ of NFN per kg of RW is excluded. Threshold NFN concentrations and masses in RW packages and batches intended for disposal should be identified based on this value taking into account NFN concentration coefficients resulting from external events and disposal system evolution, as well as errors in the calculations of NFN content in the conditioned RW. It should be noted that the errors in the calculated content of NFN in the RW conditioned for disposal purposes are quite large due to the small values of these quantities and the uncertainty associated with sampling, especially for high-level SRW. Relative errors account for $10-50 \%$ resulting in a sharp decrease of the threshold values.

To address this issue, the Nuclear Safety Department of SSC RF-IPPE developed a pilot installation with a pulsed neutron generator designed for active neutron analysis of NFN's total mass $\left({ }^{235} \mathrm{U},{ }^{239} \mathrm{Pu}\right.$, ${ }^{239} \mathrm{Pu}$ ) in 200 -liter containers (drums) containing SRW. Its standardized metrological characteristics were identified. This year, the tests are to be completed with a set of documents compiled to submit an application for the approval of the installation as a type of measuring instrument with the certification of the measurement procedure scheduled to be completed as well. A similar installation can be also developed for NZK type containers filled with SRW "in bulk", as well as for vitrified HLW in "drums" and canisters containing drums. No evidence suggesting that a similar method and installation may be used to monitor the RW emplaced into shielded transportation containers ensuring robust protection against gamma and neutron radiation and used in HLW management operations at FSUE "PA Mayak" was obtained so far.

Presented below is a more detailed discussion on the approaches applied to assess the acceptable content of NFN in various types of RWDFs.

\section{Deep disposal facilities for intermediate- level and high-level LRW}

Since 1960's, LRW containing ${ }^{235} \mathrm{U}$ and ${ }^{239} \mathrm{Pu}$ have been disposed of in deep LRW disposal facilities by waste injection into deep seated reservoir beds [13].

Research has demonstrated that there is an equilibrium of accumulation processes for the microconcentrations of nuclides contained in the LRW. The upper limit of accumulation in the rocks suggests almost linear dependence on the concentration of the nuclides in the solution. It means that due to physical and chemical processes, when the pore space of reservoir bed is filled with LRW, nuclides are distributed between the solid phase and the pore fluid and are maintained in an equilibrium state. As during the injection, new portions of waste enter the pore space of the reservoir bed, the content of the nuclide in the injected waste is taken as the equilibrium nuclide content in the pore fluid.

Geophysical studies in observation wells showed that the disposal reservoirs are filled uniformly with waste. Therefore, NFN injected with the disposed waste are distributed evenly in the rock mass. Given the above facts and extremely low concentration of californium (Cf) in the waste (less than $\left.10^{-5} \mu \mathrm{g} / \mathrm{l}\right)$, as well as its insignificant accumulation in the rocks (tenths of a microgram per liter), it was not considered in further studies.

Nuclear safety statements issued based on the review of LRW DDF design materials have specified the parameters of the facilities for the period of the planned operational life with the following criteria and findings being formulated.

For operated LRW DDF, ${ }^{239} \mathrm{Pu}$ is a nuclide that determines the critical parameters of the resulting systems. Its maximum accumulation in sandy rocks of LRW DDF Severnyi accounts for no more than $80 \mathrm{mg} / \mathrm{l}$ at the initial concentration in the LRW of $0.3 \mathrm{mg} / \mathrm{l}$. Study was performed to evaluate maximum total concentrations of ${ }^{235} \mathrm{U}$ and ${ }^{239} \mathrm{Pu}$ in the rocks of LRW DDF Severnyi which was based on research performed by the Institute of Physical Chemistry and Electrochemistry of the Russian Academy of Sciences. It was demonstrated that the maximum concentration does not exceed $100 \mathrm{mg} / \mathrm{l}$ which is ten times lower than the minimum critical concentration.

Studies performed for the Dimitrovgrad site run by FSUE NO RAO showed that corresponding concentrations were equal to 7.9 and $0.01 \mathrm{mg} / \mathrm{l}$ respectively. Conservative calculations and estimates performed for this site assuming the initial NFN concentration in LRW being equal to $0,01 \mathrm{mg} / \mathrm{l}$, showed that the concentration of NFN in the aquifer III is less than $26 \mathrm{mg} / \mathrm{l}$, in the aquifer IV - less than $3.2 \mathrm{mg} / \mathrm{l}$, which is 75 times less than the safe concentration assumed for the aquifer III and 175 times less than the one suggested for the aquifer IV.

\section{Near-surface disposal facilities \\ for solid LLW of class 3 and 4}

RW class 3 and 4 are subject to disposal in nearsurface disposal facilities. No provisions exist regarding any technological processes associated with the transformation of the waste's aggregate state prior to its near-surface disposal.

Data presented in the design documentation and safety analysis report indicate that during the predicted period of potential radiation hazard there 
will be no significant alterations in the structure of the disposed RW. Thus, if during this period of time, the requirements on the amount of NFN contained in waste packages specified for the considered NSDF type are observed, the risk of SCR is deemed as negligible.

Restrictions imposed on the mass of NFN in RW packages, the number of tiers with RW packages containing NFN in each stack and the total height of such stacks are specified to ensure nuclear safety of NSDF at all its process units and throughout its entire life cycle.

These parameters are derived based on safe surface NFN density (mass of NFN per unit of a surface area holding the RW packages). This approach is based on an assumption suggesting that the RW is compacted only "vertically" with no changes in NFN surface density (for example, due to an increase in packing layers). The criterion is used abroad and seems to be also applicable to evaluate scenarios suggesting container degradation and formation of NFN mixtures with water [14].

NSDF designs should provide for a radiation monitoring system, a system designed to monitor the state of engineered safety barriers, establishing controlled parameters and indicators to ensure safe operation of the facility. Basically, NSDF nuclear safety is demonstrated and ensured similarly to the one of temporary storage facility for nuclear materials. NFN amount contained in the RW packages subject to near-surface disposal, should be determined during SRW emplacement and indicated in RW passports.

As for uranium-containing SRW, in the long term, the mass of ${ }^{235} \mathrm{U}$ calculated per each square centimeter of any compartment's (chamber) foundation in the NSDF (surface density of ${ }^{235} \mathrm{U}$ ) should not exceed $0.043 \mathrm{~g} / \mathrm{cm}^{2}$ (a conservative value determined for a mixture of ${ }^{235} \mathrm{U}$ with carbon). This will ensure the nuclear safety of the facility under all the foreseeable NSDF operation conditions, including failure of all containers.

For SRW containing ${ }^{235} \mathrm{U}$ and ${ }^{239} \mathrm{Pu}$, its surface density per square centimeter of the NSDF should not exceed $0.031 \mathrm{~g} / \mathrm{cm}^{2}$ (a conservative assumption for a mixture of ${ }^{239} \mathrm{Pu}$ with carbon), including the case suggesting the failure of all containers.

If the waste contains uranium with ${ }^{235} \mathrm{U}$ enrichment of up to $20 \%$, its concentration shall satisfy the following requirements:

- packages assembled using NZK-MR containers and drums should contain no more than $8.7 \cdot 10^{-5}$ grams of ${ }^{235} \mathrm{U}$ per $\mathrm{cm}^{3}$ of waste (provided that no more than one layer of NZK-MR and two layers of stands with drums are emplaced into one RW stack);
- packages assembled using NZK-150-1,5P, ZhZK-2, NZK-P, NZK-Radon, ZhBU, ZhZK containers should contain no more than $2.4 \cdot 10^{-5}$ grams of ${ }^{235} \mathrm{U}$ per $\mathrm{cm}^{3}$ of radioactive waste with the mass of ${ }^{235} \mathrm{U}$ in the packages not exceeding the following limits:

- NZK-150-1.5P, ZhZK-2, NZK-P - 36.0 g;

- NZK-Radon - $45.6 \mathrm{~g}$;

- NZK-MR - $165.3 \mathrm{~g}$ (provided that the stack is composed of maximum 1 layer);

- ZhBU, ZhZK - $23.0 \mathrm{~g}$;

- drum - $16.8 \mathrm{~g}$ (provided that the stack is composed of maximum 2 layers);

- KMZ - 74.4 g;

- Krad-1.36 - $32.6 \mathrm{~g}$.

For radioactive waste containing uranium, plutonium, americium, curium, the total volume concentration of ${ }^{235} \mathrm{U}$ and ${ }^{239} \mathrm{Pu}$ should not exceed $3.0 \cdot 10^{-5} \mathrm{~g}$ per $\mathrm{cm}^{3}$ of the waste, and the total mass of ${ }^{235} \mathrm{U}$ and ${ }^{239} \mathrm{Pu}$ in waste packages should not exceed the following values:

- NZK-150-1.5P, ZhZK-2, NZK-2, NZK-P - 45.0 g;

- NZK-Radon, NZK-MR, ZhZK - 57.0 g;

- ZhBU, ZhZK - 28.8 g;

- 2001 drum $-6.0 \mathrm{~g}$;

- $\mathrm{KMZ}-93.0 \mathrm{~g}$.

\section{Deposal facilities for high-level SRW}

RW DDF project implemented in Russia is currently at stage of underground research laboratory (URL) construction which is built in crystalline rocks of the Nizhnekanskiy rock mass (Krasnoyarsk Territory). Criticality assessments for the RW DDF both covered its operation stage and the long-term perspective (post-closure stage). These assessments considered the processes resulting in the degradation of waste packages and engineered safety barriers.

${ }^{239} \mathrm{Pu}$ and ${ }^{235} \mathrm{U}$ were considered as NFNs. The integrity of RW packages and their ability to contain the radioactive material is maintained at DDF RW operational stage.

However, in the long-term, after RW DDF closure, gradual degradation of the packaging material and engineered safety barriers is expected resulting in the redistribution of fissile and other materials which can potentially lead to the formation of NFM composition with greater reactivity compared to the one of RW at the stage of RW DDF operation.

To ensure nuclear safety of the Nizhnekanskiy RW DDF considering all types of RW class 2 packages, the safe total mass of ${ }^{239} \mathrm{Pu}$ and ${ }^{235} \mathrm{U}$ accounts for $50 \mathrm{~g}$ in case of weapons-grade fissile nuclear materials (NFM) and $100 \mathrm{~g}$ for RW generated at NPPs or from SNF reprocessing. For a canister containing 
RW class 1 (vitrified HLW shipped from PA Mayak site), the safe total mass of ${ }^{239} \mathrm{Pu}$ and ${ }^{235} \mathrm{U}$ is assumed to be $77 \mathrm{~g}$. At present, no reliable data is available on NFM content of RW class 2, which will be delivered to Nizhnekanskiy RW DDF from nuclear fuel cycle facilities.

In accordance with federal norms and rules [9], the National Operator shall ensure the development of acceptance criteria for vitrified HLW sent to RW DDF. These acceptance criteria shall specify the content of NFM in the waste. Existing RW DDF design documentation sets forth the acceptability criteria regarding the mass of NFM contained in the canisters with vitrified HLW. Research performed has enabled to clarify relevant values for the mass of NFM in canisters with aluminum-phosphate glass. It appeared that the total mass of ${ }^{239} \mathrm{Pu}$ and ${ }^{235} \mathrm{U}$ for more than $95 \%$ of the canisters concerned exceeds the design limit, and the mass of ${ }^{239} \mathrm{Pu}$ in various canisters differs by more than a hundred times, whereas the one of ${ }^{235} \mathrm{U}$ - by more than ten times. The upper range of ${ }^{235} \mathrm{U}$ and ${ }^{239} \mathrm{Pu}$ total mass content in the canisters is comparable with the one found in VVER-440 spent nuclear fuel. These findings suggest that certain refinement of the acceptance criteria set for the considered RW DDF should be done.

Under such circumstances, the following approach should be applied to develop waste acceptance criteria: the total content of ${ }^{235} \mathrm{U}$ and ${ }^{239} \mathrm{Pu}$ in each canister and disposal borehole containing several canisters should be limited with relevant values identified during the packaging (repackaging) of canisters containing drums with vitrified waste, their handling and storage in disposal boreholes. This should be done taking into account the layout of canisters and boreholes based on an assumption suggesting that during operation and in the long term after disposal facility's closure, NFN will not leak from the boreholes and further concentrated resulting in the formation of a supercritical system.

Moreover, there are other factors that can affect the criticality of the system. For example, changes in the stress state of a rock mass or minor seismic effects can affect the position of RW packages resulting in the redistribution or accumulation of NFM from several packages with a higher reactivity geometric configuration being formed. Therefore, it seems problematic to apply surface density limitation for NFM in RW DDF as it's done in case of nearsurface disposal facilities.

To enable decision making on nuclear safety standards for the disposal of canisters with vitrified HLW containing NFN in excess of relevant safe values, additional studies should be performed. These should be aimed at clarifying the scenarios and their consequences for RW DDF evolution, as well as acceptance criteria for such SRW disposal.

If it's demonstrated that even after the forecasted period of RW DDF's potential hazard, no redistribution and concentration of uranium and plutonium occurs, for example, as a result of sorption-desorption, diffusion, then the ratio of ${ }^{239} \mathrm{Pu}$ and ${ }^{235} \mathrm{U}$ sum to uranium (the so-called effective enrichment in the waste) averaged over a disposal borehole can be used as a nuclear safety parameter. The threshold value will depend on the composition of the mixture containing the NFN and on the ratio of ${ }^{239} \mathrm{Pu}$ and ${ }^{235} \mathrm{U}$. Requirements and nuclear safety standards set for the stage of RW DDF operation and the forecast period after its closure are established based on the state of drums, canisters with HLW, radionuclide migration in engineered safety barriers and rocks in the RW DDF area, considered in the designs and safety analysis report.

It should be noted that IAEA recommendations and safety guidelines covering pre-disposal management and disposal of radioactive waste in NSDF and RW DDF have been put into effect [15-18]. These present general requirements for safety analysis and safety demonstration provided for relevant disposal facilities, including those concerning the nuclear safety.

Some studies were performed abroad to estimates the parameters and consequences of the SCR for RW DDF models covering a period following the expiration of the forecast one [19-21] assuming a long-term formation of the critical system, slow increase and subsequent quenching of reactivity. Duration of pulsating (wave-like) SCR phase for such models was found to be more than one hundred years. The validity of the assumptions applied is both difficult to refute and to confirm. It should be noted that SCR results in the formation of noble radioactive gases and cesium-137, which can potentially reach the surface. To evaluate the activity of such discharge is no less difficult than to estimate the SCR parameters, since in this case the system parameters and the geological structure of the considered rock mass are to be known.

We believe that the following considerations are to be taken into account as well. Information on mineral deposits evidences that over millions of years natural processes have the ability to separate elements and concentrate simple substances of naturally occurring elements (oxides, including uranium, fluorides, etc.) and even metals (gold, silver, etc.) in separate locations resulting in their huge quantities. A quasi-homogeneous natural uranium oxide reactor (Oklo phenomenon) is well known. Based on this fact, uranium-containing RW should be "downblended" before disposal so that 
${ }^{235} \mathrm{U}$ content in uranium accounts for less than $1.5 \%$ Then in "quasi-homogeneous" medium (without any man caused heterogeneity), SCR is excluded for any content of ${ }^{235} \mathrm{U}$ being present in any mixture. In terms of uranium and transuranic NFN containing RW disposal, one should at least demonstrate that their separation is not possible and determine the threshold ratio of NFN to the sum of "non-fissile" nuclides (primarily ${ }^{238} \mathrm{U},{ }^{240} \mathrm{Pu}$ and ${ }^{238} \mathrm{Pu}$ ) in the NFM containing RW subject to disposal (uranium, plutonium, neptunium, americium).

\section{Conclusion}

Nuclear safety of disposal facilities for NFN containing RW should be demonstrated with due account of the predicted scenarios for RW DDF evolution, which is done for a time period limited by our knowledge on the geological structure of the siting area and its evolution scenarios. In terms of nuclear safety, concentration of NFN in LRW and its mass, as well as NFN contents in SRW packages is believed to be the main criterion manifesting the acceptability of RW for deep geological disposal. Values of the parameters are determined based on the nuclide composition of the waste and the predictions regarding RW DDF state during its operation and in the long term (after its closure) with relevant data presented in the designs and the safety analysis reports.

RW parameters being identified based on relevant measurements performed during waste conditioning, are indicated in passports filled in for each batch, RW package and should be monitored upon waste receipt at the disposal facility. High-resolution detectors installed outside of metal and concrete NZK, ZhBU, ZhZK, Krad, KMZ type containers can be used to perform validating gamma-spectrometric measurements to determine the activity of the key technogenic long-lived gamma-active radionuclides in containers with quasi-homogeneous SRW. Active neutron method with a pulsed neutron generator can be used to validate the measurements of NFN mass (content) in such containers.

To demonstrate that the possibility of SCR can be excluded for RW DDF's siting region and for a time period beyond the forecast one, one should identify the parameters of the system, the mechanisms enabling the suppression of SCR after the expiration of the forecast period requiring some further studies to be performed.

\section{References}

1. Federal'nyj zakon Rossijskoj Federacii ot 11 iyulya 2011 g. no 190-FZ «Ob obrashchenii s radioaktivnymi othodami i o vnesenii izmenenij v otdel'nye zakonodatel'nye akty Rossijskoj Federacii» [Federal Law of July 11, 2011 no 190-FZ “On Management of Radioactive Waste and Amendment of some acts of Law of the Russian Federation"].

2. Postanovlenie Pravitelstva RF ot 19.10.2012 no 1069 «O kriteriyah otneseniya tverdyh, zhidkih i gazoobraznyh othodov $\mathrm{k}$ radioaktivnym othodam, kriteriyah otneseniya radioaktivnyh othodov $\mathrm{k}$ osobym radioaktivnym othodam i k udalyaemym radioaktivnym othodam i kriteriyah klassifikacii udalyzemyh radioaktivnyh othodov [Decree of the Government of the Russian Federation of 19 October 2012, no. 1069 "On the criteria of designation of solid, liquid and gaseous waste as radioactive waste, criteria of radioactive waste designation as special radioactive waste and removable radioactive waste and criteria of classification of removable radioactive waste"].

3. Federal'nye normyi pravilavoblastiispol'zovaniya atomnoj energii «Obshchie polozheniya obespecheniya bezopasnosti ob"ektov yadernogo toplivnogo cikla» (NP-016-05) [Federal Norms and Rules in Field of Atomic Energy Use "General Safety Provisions for Nuclear Fuel Cycle Facilities"] / Utv. postanovleniem Federal'noj sluzhby po ekologicheskomu, tekhnologicheskomu i atomnomu nadzoru ot 2 dekabrya $2005 \mathrm{~g}$ no 11.

4. Federal'nye normy i pravila $\mathrm{v}$ oblasti ispol'zovaniya atomnoj energii «Pravila yadernoj bezopasnosti dlya ob"ektov yadernogo toplivnogo cikla» (NP-063-05) [Federal Norms and Rules in Field of Atomic Energy Use "Nuclear Safety Rules for Nuclear Fuel Cycle Faculties" (NP-063-05)] / Utv. postanovleniem Federal'noj sluzhby po ekologicheskomu, tekhnologicheskomu i atomnomu nadzoru ot 20 dekabrya $2005 \mathrm{~g}$ no 15 .

5. Federal'nye normy i pravila $\mathrm{v}$ oblasti ispol'zovaniya atomnoj energii «Osnovnye pravila ucheta $\mathrm{i}$ kontrolya yadernyh materialov» (NP-030-12) [Federal Norms and Rules in Field of Atomic Energy Use "Basic Rules on Accounting and Control of Nuclear Materials” (NP-030-12)] / Utv. prikazom Federal'noj sluzhby po ekologicheskomu, tekhnologicheskomu i atomnomu nadzoru ot 15 aprelya $2012 \mathrm{~g}$ no 255 .

6. Federal'nye normy i pravila $\mathrm{v}$ oblasti ispol'zovaniya atomnoj energii «Osnovnye pravila ucheta i kontrolya radioaktivnyh veshchestv i radioaktivnyh othodov v organizacii» (NP-067-16) [Federal Norms and Rules in Field of Atomic Energy Use "Basic Rules on Accounting and Control of Radioactive Materials and Radioactive Waste in Organizations" (NP-06716)] / Utv. prikazom Federal'noj sluzhby po ekologicheskomu, tekhnologicheskomu i atomnomu nadzoru ot 28 noyabrya $2016 \mathrm{~g}$ no 503.

7. STO 95 12001-2016 Osnovnye pravila yadernoj bezopasnosti pri proizvodstve, ispol'zovanii, pererabotke, hranenii i transportirovanii yadernyh 
delyashchihsya materialov (PBYA-06-00-2016) [STO 95 12001-2016 Basic Nuclear Safety Rules for manufacturing, Use, Processing, Storage and Transportation of Fissile Nuclear Materials (PBYa-06-00-2016)]. 8. STO 95 12002-2016 Pravila yadernoj bezopasnosti pri hranenii i transportirovanii yadernyh delyashchihsya materialov (PBYA-06-09-2016) [STO 95 12002-2016 Nuclear Safety Rules for Storage and Transportation of Nuclear Fissile Materials (PBYa-06-09-2016)].

9. Federal'nye normy i pravila v oblasti ispol'zovaniya atomnoj energii «Kriterii priemlemosti radioaktivnyh othodov dlya zahoroneniya» (NP-093-14) [Federal Norms and Rules in Field of Atomic Energy Use "Radioactive Waste Acceptance Criteria for Disposal” (NP-093-14)] / Utv. prikazom Federal'noj sluzhby po ekologicheskomu, tekhnologicheskomu $\mathrm{i}$ atomnomu nadzoru ot 15 dekabrya $2014 \mathrm{~g}$ no 572 . 10. Federal'nye normy i pravila v oblasti ispol'zovaniya atomnoj energii «Pripoverhnostnoe zahoronenie radioaktivnyh othodov. Trebovaniya bezopasnosti» (NP-069-14) [Federal Norms and Rules in Field of Atomic Energy Use "Near-Surface Disposal of Radioactive Waste. Safety Requirements" (NP069-14)] / Utv. prikazom Federal'noj sluzhby po ekologicheskomu, tekhnologicheskomu i atomnomu nadzoru ot 6 iyunya $2014 \mathrm{~g}$ no 249.

11. Federal'nye normy i pravila $\mathrm{v}$ oblasti ispol'zovaniya atomnoj energii «Zahoronenie radioaktivnyh othodov. Principy, kriterii i osnovnye trebovaniya bezopasnosti» (NP-055-14) [Federal Norms and Rules in Field of Atomic Energy Use "Radioactive Waste Disposal. Principles, Criteria and Main Safety Requirements" (NP-055-14)] / Utv. prikazom Federal'noj sluzhby po ekologicheskomu, tekhnologicheskomu i atomnomu nadzoru ot 22 avgusta $2014 \mathrm{~g}$ no 379.
12. Federal'nye normy i pravila v oblasti ispol'zovaniya atomnoj energii «Trebovaniya k sostavu i soderzhaniyu otcheta po obosnovaniyu bezopasnosti punktov zahoroneniya radioaktivnyh othodov» (NP-100-17) [Federal Norms and Rules in Field of Atomic Energy Use "Requirements on the Contents and Structure of Safety Analysis Reports for Radioactive Waste Disposal Facilities" (NP-100-17)] / Utv. prikazom Federal'noj sluzhby po ekologicheskomu, tekhnologicheskomu i atomnomu nadzoru ot 23 iyunya $2017 \mathrm{~g}$ no 218.

13. Rybalchenko A. I., Pimenov M. K. i dr. Glubinnoe zahoronenie zhidkih radioaktivnyh othodov [Deep Disposal of Radioactive Waste]. Moscow, IzdAT Publ., 1994. $257 \mathrm{p}$.

14. Hopper C. H., Elfm K. E., Panks C.V.// Proceedings of the Meeting. Criticality Safety Challenges in the Next Decade. ORNL USA. ANS, 1997.

15. Storage of Radioactive Waste. Safety Guide. No WS-G-6.1.2006.

16. The Safety Case and Safety Assessment for the Predisposal Management of Radioactive Waste. General Safety Guide. No GSG-29. 2014.

17. Near Surface Disposal Facilities for Radioactive Waste. Specific Safety Guide. No SSG-29. 2014.

18. The Safety Case and Safety Assessment for the Predisposal Management Waste. Specific Safety Guide. NoSSG-23. 2012.

19. Long-Term Criticality Safety Concerns Associated with Weapons-Plutonium Disposition. Research Grant NATO No SA/12-1-02 (DISRM.CRG941318).

20. Forsberg C. W. Long-Term Criticality Control in Radioactive Waste Facilities. Nuclear Safety, Vol. 38, No 1, January-March 1997.

21. Bowman C. D., Venneri F. Autocatalytic Criticality from Plutonium and Other Fissile Material. Science \& Global Security, vol. 5, 1996.

\section{Information about the authors}

Vnukov Viktor Sergeevich, PhD, Senior Researcher, Joint Stock Company "State Scientific Centre of the Russian Federation - Institute for Physics and Power Engineering named after A. I. Leypunsky" (1, Bondarenko square, Obninsk, Kaluga region, 249033, Russia), e-mail: ryazanov@ippe.ru.

Ryazanov Boris Georgievich, PhD, Deputy Chief Engineer, Joint Stock Company "State Scientific Centre of the Russian Federation - Institute for Physics and Power Engineering named after A. I. Leypunsky" (1, Bondarenko square, Obninsk, Kaluga region, 249033, Russia), e-mail: ryazanov@ippe.ru.

Sviridov Viktor Ivanovich, Head of Laboratory, Joint Stock Company “State Scientific Centre of the Russian Federation - Institute for Physics and Power Engineering named after A. I. Leypunsky” (1, Bondarenko square, Obninsk, Kaluga region, 249033, Russia), e-mail: ryazanov@ippe.ru.

\section{Bibliographic description}

Vnukov V. S., Ryazanov B. G., Sviridov V. I. Nuclear Safety of Disposal Facilities for Radioactive Waste Containing Fissile Nuclear Materials. Radioactive Waste, 2019, no. 3 (8), pp. 44-52. DOI: 10.25283/25879707-2019-3-44-52. (In Russian). 